\title{
Essential Meeting Information
}

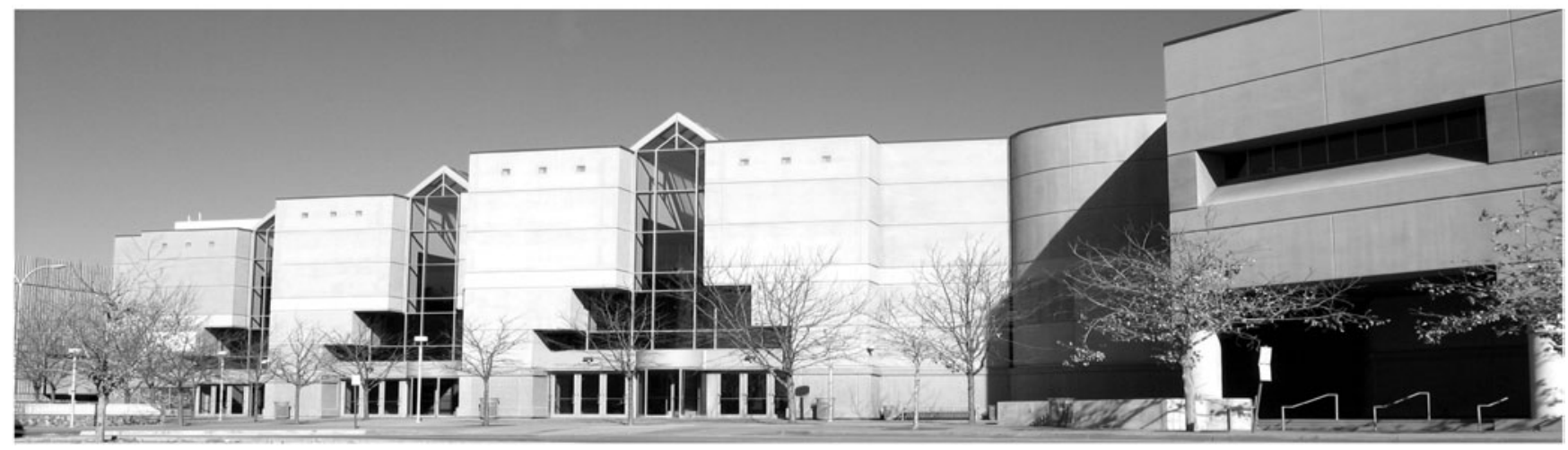

\section{The Albuquerque Convention Center}

\section{Business AND CommitTee MeEtings}

\section{Friday, August 1}

MSA Council Meeting 7:30 AM-5:30 PM San Miguel

Saturday, August 2

MSA Council Meeting

IMS Board Meeting

IMS Poster Judging

Sunday, August 3

MAS Council Meeting

MAM Editors Meeting

Monday, August 4

MSA Awards Meeting

TF Board Meeting

MAM Editorial Board

M\&M 2009 Program

Planning Meeting

\section{Tuesday, August 5}

MSA LAS Meeting

2009 Call for Papers

MSA International

Committee

FIG Business Meeting

MSA Education

Committee

7:30 AM-5:30 PM San Miguel 8:00 AM-5:00 PM Pecos 8:00 AM-5:00 PM Pecos

7:30 AM-5:30 PM Ruidoso 3:00 PM-5:00 PM Zuni

7:00 AM-8:00 AM 7:00 AM-9:00 AM 7:15 AM-8:15 AM

Tesuque Acoma Zuni 3:30 PM-5:00 PM Zuni

7:00 AM-8:30 AM Santa Ana/ Sandia

10:00 AM-12:00 PM Zuni 3:30 PM-5:00 PM Zuni

3:30 PM-5:00 PM 3:30 PM-5:00 PM

Acoma

San Juan

3:30 PM-5:00 PM San Juan

Wednesday, August 6

MSA Certification Board 2009 EXPO Meeting

MSA Business Meeting
MAS Affiliated Regional

Societies

IMS General Members'

Technologists' Forum

MSA Standards Subcommittee

(Note New Time and Day)

MSA Public Policy

Committee

MAS Business Meeting

Thursday, August 7

MSA/MAS Sustaining

Members Meeting
7:00 AM-9:00 AM Zuni 9:00 AM-10:00 AM Acoma

12:15 PM-1:15 PM Brazos

12:15 PM-1:15 PM Cochiti

12:15 PM-1:15 PM Pecos 3:00 PM-3:30 PM Acoma 3:30 PM-4:30 PM Tesuque

3:30 PM-5:00 PM Zuni

5:15 PM-6:15 PM Aztec

7:00 AM-9:00 AM Tesuque

\section{Local Arrangements Committee Booth-Albuquerque}

Stop by the M\&M 2008 LAC Booth for the locals' perspective on all there is to see and do in Albuquerque! Located in the main registration lobby, next to the Concierge booth, and staffed during main meeting hours. 


\section{MicRosCOPY \& MicroANALYSIS Registration Fees}

- Registration can be done either online at: http://mm 2008.microscopy.org or on-site at the meeting registration desk.

- Copies of the Proceedings are to be picked up at the registration desk during the meeting.

- Member rates apply to members of all sponsoring societies

\section{Meeting}

\section{Registration Prices}

Full Registration (member)

Full Registration (member) (MSA/MAS/IMS)

Full Registration (Non-member)

Student Member (proof of status required)

Student Non-Member*

Emeritus (members only)*

One Day*

Two Day*

Exhibits Only

$\begin{array}{ll}\text { Before } & \text { On or after } \\ \text { July 3 } & \text { July } 4 \\ \$ 350 & \$ 450\end{array}$

Full Meeting \& One In-week Workshop

(X19, X20, X26, Mon.-Thurs.-See Page 46 for details)

Member

$\$ 850 \$ \$ 850$

Non-Member

$\$ 850 \quad \$ 850$

\section{Pre-Meeting Congress}

(X1, X2 Saturday \& Sunday-See Page 22 for details)

Member

$\$ 160 \$ 230$

Non-Member

$\$ 185 \$ 230$

\section{Short Courses}

(X11, X14, X16, X17, or X18 Sunday-See Pages 24-25 for details)

Member $\$ 150 \quad \$ 220$

Non-Member $\$ 175 \quad \$ 220$

Short Course (X13 Sunday-See Page 24 for details)

Member

$\$ 215 \$ 285$

Non-Member $\$ 250 \quad \$ 285$

Short Course (X12 Sunday Half Day-See Page 24 For details)

Member

$\$ 95 \quad \$ 125$

Non-Member

$\$ 105 \$ 125$

\section{Social Event Fees}

Sunday Reception (Full Registration includes 1 ticket.)

Additional tickets:
Adult
$\$ 60$
Child (ages 3-11 yr)
(under 3 yr)
IMS Awards Banquet
$\$ 15$
Free
$\$ 60$
$\$ 100$
Golf Tournament

${ }^{\star}$ Only Full Registrants receive a copy of the Proceedings and a ticket to the Sunday Reception.

\section{M\&M 2009 MeEting Information}

Get the inside scoop on all the great plans for next year's M\&M Meeting in historic and charming Richmond, Virginia! A representative from the Greater Richmond Convention \& Visitors Bureau will be on hand to answer questions and distribute information about Virginia's capital city. The Richmond booth is located in the main registration lobby, next to the Albuquerque LAC Booth, and staffed during main meeting hours.

\section{MSA Megabooth \\ [BOOTH 130-SEE DETAILS ON PAGE 20]}

Check out all that MSA has to offer its members and M\&M attendees: Free Cyber Café, book display from scientific publishers, updated information on the Certification Board, and a DVD Library. Register for the popular Exhibitor Tutorials, sign up for MSA Membership, check out recent editions of Microscopy Today, learn about Project MICRO and join the Technologists' Forum.

\section{PAYMENT}

All Prices are in US dollars. Payment can be by cash, money order, check (U.S. funds only) or credit card (Visa/ Mastercard/American Express.) Student registration is restricted to current MSA, MAS, IMS Student Members and to other bona fide full time students who can document that status at the time of registration. Emeritus Registration is for Emeritus Members of the sponsoring societies only. There is no charge for admission to view the commercial exhibits only; however, registration is required.

\section{Proceedings}

Conference Proceedings are distributed at Registration. All Full Meeting registrations include a printed and CD-ROM proceedings.

\section{Registration Cancellation Policy}

Refund requests will be honored (less $\$ 50$ processing fee) if received in writing by July 17,2008. E-mail: MMRegistration@ conferencemanagers.com or fax 703-964-1246. No refunds will be given after July 17, 2008. No-shows are nonrefundable. No cancellations will be accepted for social event tickets. The MSA's Federal ID and tax-exempt \# is 116-042-333. 


\section{Registration Desk}

The Registration Desk at M\&M 2008 is located in the main lobby in the East Building. Pick up your badge and tote bag, buy additional reception tickets, and/or register onsite. Registration hours are as follows:

$\begin{array}{ll}\text { Thursday, July 31 } & \text { 12:00 PM-5:00 PM (exhibitors only) } \\ \text { Friday, August 1 } & \text { 10:00 AM-7:00 PM } \\ \text { Saturday, August 2 } & \text { 6:30 AM-5:00 PM } \\ \text { Sunday, August 3 } & \text { 6:30 AM-8:00 PM } \\ \text { Monday, August 4 } & \text { 7:00 AM-6:00 PM } \\ \text { Tuesday, August 5 } & \text { 7:30 AM-5:00 PM } \\ \text { Wednesday, August 6 } & \text { 7:30 AM-5:00 PM } \\ \text { Thursday, August 7 } & \text { 7:30 AM-3:00 PM }\end{array}$

\section{Shuttle Bus Schedule}

All hotels (except Hyatt and Doubletree) are serviced by M\&M shuttle buses to and from the convention center. Please see separately printed schedule, as well as signage at hotels and at the convention center.

\section{SOCIETY BOOTHS}

MAS and IMS each have a membership and information booth located adjacent to the main registration lobby and the exhibit hall entrance. Sign up for membership, get information on Society events at or after the M\&M Meeting, and check out all that the joining societies have to offer!

\section{Albuquerque Convention Center Information}

\section{Albuquerque Visitor Information}

Get visitor and tourist information on Albuquerque at the city's concierge booth in the registration lobby. Find great restaurants, find tickets for a balloon ride or scenic tour, and get information on where to buy the best souvenirs! Booth will be staffed during main meeting hours.

\section{DISABILITY}

If you require special accommodations in order to participate fully in the meeting, please ask to speak with the meeting manager, or email MeetingManager@microscopy. org. Requests made after July 1 or onsite at the meeting will be accommodated as much as possible.

\section{Phone Numbers}

Albuquerque Convention Center Main

$505-768-4575$

M\&M 2008 Information/Registration Desk

Albuquerque Visitors Bureau

Albuquerque Events Hotline

1-800-284-2282 (24 h)

Emergency Room-Heart Hospital of NM 505-724-2000

STATMed Urgent Care Clinic

\section{INTERNET AND E-MAIL}

Free wireless internet is available in the public lobby spaces at the Albuquerque Convention Center (East and West buildings). (Service does not necessarily extend into meeting rooms.) Check your email and surf the web at the Cyber Café inside the exhibit hall during exhibit hours (located next to the MSA MegaBooth). For more information on the MegaBooth, go to page 20.

\section{HOTEL INFORMATION}

Official M\&M Meeting Hotels_-distance from convention center/phone number:

- Hyatt Regency-1 block/505-842-1234

- Doubletree-1 block/505-247-3344

- Embassy Suites (shuttle service available)—- $\frac{3}{4}$ mile/ 505-247-1083

- HiIton (shuttle service available) -3 miles/505-884-2500

- Fairfield Inn (shuttle service available)-3 miles/ 505-889-4000

- Plaza Inn (shuttle service available)—- $\frac{3}{4}$ mile/505-243-5693 


\section{VOLUNTEERS}

The volunteer \& student bursary office is in the East Building on the Upper Level (Office G). Check in here for volunteer assignments and sign-outs.

\section{Business Center}

PSAV operates a business center in the West Building, Lower Level, during extended business hours. Copies, fax, supplies, and shipping are available for a fee.
FoOd fOR PURChASE

Inexpensive, portable breakfast and snack items are available for purchase in the public spaces at the convention center (7:30 AM-10:30 AM). Lunch concessions are available for purchase inside the exhibit hall during lunch hours (11:30 AM-1:30 PM).

\section{SMOKING Policy}

M\&M 2008 is a smoke-free meeting. If you wish to smoke, please go outside or to your hotel room.

\section{What Can I Do in Albuquerque?}

Albuquerque, New Mexico is the unofficial capital of the authentic Southwest and a place where spectacular culture, nearly unlimited activities, and breathtaking landscape all converge for a truly unique vacation destination!

Albuquerque is the Ballooning Capital of the World. At no time is this more evident than in October during the world-famous Balloon Fiesta, but even in the rest of the year there are numerous hot-air and gas balloon adventures to be had. Be sure to visit the city's International Ballooning Museum, the world's premier facility dedicated to the art, culture, science, history and sport of hot air ballooning. Check out http://www.itsatrip.org/activities/hotair-ballooning/default.aspx for a complete listing of balloon companies in the Albuquerque area for information and pricing on rides and packages for one or more people (some including souvenir pictures, wine glasses, etc.).

Albuquerque's unique history includes not only the past 300 years (the city just celebrated its tricentennial), which brought Spanish explorers and settlers to the region, but also original Pueblo culture dating back thousands of years. Numerous self-guided tour itineraries are available on at http://www.itsatrip.org/activities/tours-trails/self-tours. aspx including several walking tours downtown and in various neighborhoods.
Get Your Kicks ... Take a self-guided Route 66 Tour (4 hours; 4.2 miles) through downtown Albuquerque on the old "Mother Road"-U.S. Route 66 (now Central Avenue). Download a self-guided tour map at http://www.itsatrip.org/ albuquerque/historic-route-66/route-66-tour.aspx.

Do you love the nightlife? The Albuquerque area has eight (8) casino and gaming venues, owned and operated on Pueblo land. Details are available at any hotel concierge, or stop by the Albuquerque desk in the registration area for casino hours, amenities, and locations.

Albuquerque's Rio Grande Valley is the oldest winemaking region in the country! Numerous wineries call Albuquerque home, and offer tours and tastings that allow you to walk among vineyards, observe the wine-making process, and taste the results. Check with the concierge desk for directions, hours, and events at each winery.

Don't miss the stunning views of the city from the Sandia Peak Aerial Tramway, a unique attraction that starts in the foothills and slowly, over 2.7 miles, climbs to the top of the 10,350-foot peak of the mountains on Albuquerque's eastern side. At the top, you can see over 11,000 square miles below, including the city lights of Albuquerque. Operates 9:00 AM-9:00 PM in July and August. (Admission Fee.) 


\section{M\&M 2008-Social Events}

\section{Sunday Reception at the Zoo!}

Catch up with friends and colleagues, and bring your family and guests! The Sunday Reception is being held at the beautiful Rio Grande Zoo, part of the unique and worldrenowned Albuquerque Biological Park complex. Enjoy a delicious buffet dinner featuring New Mexican cuisine, relax to the sounds of a local Mariachi band, and see some of the zoo's wonderful animal exhibits. Beer, wine, and margaritas will be "on the house" (ID required). One admission is included with all Full Meeting registrations. If you wish to purchase additional tickets, please go to the registration desk at the Convention Center (subject to availability).

Tickets are $\$ 60$ each per adult. Event starts at 6:30 PM and ends at 9:30 PM. Complimentary shuttle bus transportation will be provided between hotels and the zoo.

\section{MAS SOCIAL-FOR MAS Members Only!}

Stop by the MAS booth (just outside the exhibit hall entrance) to check your membership status and pick up your ticket for the MAS Social on Wednesday evening, August 6-immediately following the Business Meeting.

\section{IMS Awards Banquet}

Be sure to buy your ticket (available at Registration) and stop by the IMS booth for additional information on the IMS Awards Banquet on Wednesday evening, August 6.

\section{Annual M\&M Golf Tournament}

The annual golf tournament is on Sunday, August 3 at the beautiful Sandia Golf Club at the Sandia Resort and Casino. This course has an elevation of 5,300 feet above sea level with great views of the Sandia Mountains, and features 7,772 yards of play from the back tees. The $\$ 100$ registration fee covers transportation, greens fees, golf cart, box lunch and polo shirt. (Rental clubs are available at the pro shop at the resort.) Tee times start at 9:30 AM. Complimentary shuttle bus departs the convention center at 7:45 AM on Sunday morning. There is only ONE bus-so don't be late! Prizes are offered for best team scores and special additional prizes will be offered as well. Come golf one of the finest courses around, and enjoy unique New Mexican scenery!

\section{Tramway Tour Package-Just for M\&M 2008 ATtENDEES!}

\$70/person-Wednesday, August 6

Bus departs at 5:30 PM-dinner at 7:00 PM

All aboard for a fun and uniquely "Albuquerque" adventure as we board the bus for a spectacular evening. The bus will take you to the foothills of the Sandia Mountains, where you'll board the Aerial Tramway for a 20-minute ride to the top. Spend some time gazing at the awesome views and scenery spread out below. Then join everyone for a delicious dinner at High Finance, the only restaurant at the top of the mountain! Watch the sun set, then head back to town. It will be an evening to remember! (Check the mm2008.microscopy.org website for detailed information on pricing and registration.)

\section{Future Meetings}

Microscopy \& Microanalysis 2009

Sponsored by MSA, MAS, and IMS

July 26-30, in Richmond, Virginia

Microscopy \& Microanalysis 2010

Sponsored by MSA, MAS, and IMS

August 1-5, in Portland, Oregon

Microscopy \& Microanalysis 2011

Sponsored by MSA, MAS, and IMS

August 7-11, in Nashville, Tennessee 